\title{
Inhibitory effects of Azadirachta indica secondary metabolites formulated cosmetics on some infectious pathogens and oxidative stress radicals
}

\author{
Sunday O. Okoh ${ }^{1,2,3^{*}}$ (D, Omobola O. Okoh ${ }^{4}$ and Anthony I. Okoh ${ }^{1,2}$
}

\begin{abstract}
Background: Infectious diseases, particularly those due to multi-drug resistant bacterial strains are almost impossible to cure globally. In this study we investigated the inhibitory effects of Azadirachta indica A. Juss secondary metabolites (AISM) formulated soap and cream for management of infectious and oxidative stress-related diseases (OSD).

Methods: The antibacterial, radical scavenging and cytotoxic effects of the neem cosmetics were examined by serial dilution, spectrophotometric and hemolytic techniques respectively, while the AISM in the essential oils (EOs) were elucidated by Gas chromatography-mass spectrometry (GC-MS) and retention index.

Results: The neem cosmetics without AISM exhibited bacteriostatic effects against five reference bacterial strains (Staphylococcus aureus, Listeria ivanovii, Enterobacter cloacae, Mycobacterium smegmatis, and Streptococcus uberis) and two confirmed multi-drug resistant bacterial strains (Vibrio paraheamolyticues, Escherichia coli 180) at 0.80 $\mathrm{mg} / \mathrm{mL}$. Conversely, at less than $0.50 \mathrm{mg} / \mathrm{mL}$ the neem soap produced with AISM demonstrated bactericidal effects against most of these test pathogens linked to infectious diseases. The neem soap containing AISMs displayed noteworthy effects in scavenging radicals associated with OSD at $<1.76 \mathrm{mg} / \mathrm{mL}$. The cosmetics were not toxic to human red blood cells below $0.70 \mathrm{mg} / \mathrm{mL}$. To our known, the AISM predominantly caryophyllene (30.02\%), phytol (14.12\%), elemene (13.40\%) and linoleic acid (10.5\%) exceptional inhibitory effects in neem cosmetics are reported here for the first time.

Conclusion: The study indicates that apart from traditional uses of $A$. indica, the EO contained potent bioactive AISM and feasible as an antimicrobial agent, an alternative to synthetic antioxidant, likewise considered novel in the pharmaceutical, cosmetics industries and as food preservatives.
\end{abstract}

Keywords: Azadirachta indica, Secondary metabolites, Bactericidal, Radical scavenger, Neem cosmetics

\section{Background}

The discovery of antibiotics created high hope for management for both infectious and non-communicable diseases, but these hopes have been decreased by the emergence of antibacterial resistant pathogens. Antimicrobial resistance has been listed as one of the top 3 threats

\footnotetext{
* Correspondence: sokoh@ufh.ac.za; sunnyokoh632@yahoo.co.uk

${ }^{1}$ SAMRC Microbial Water Quality Monitoring Center, University of Fort Hare, Alice, South Africa

${ }^{2}$ Applied and Environmental Microbiology Research Group (AEMREG),

Department of Biochemistry and Microbiology, University of Fort Hare,

Private Mail Bag X1314, Alice, Eastern Cape, South Africa

Full list of author information is available at the end of the article
}

to global public health [1]. Bacteria strains including Escherichia coli, vancomycin-resistant Enterococcus faecalis, Vibrio Spp., and methicillin-resistant Staphylococcus aureus (MRSA) are known public threats in hospitals and have become more resistant because of natural selection processes, and over-prescription and misuse of antibiotics [2]. A novel curative agent is desirable which would have to be distinct from current classes of antibiotics to alleviate problems with cross-resistance and co-resistance of microbes [3]. Pharmaceutical industries are unwilling to invest large sums of money into the development of new synthetic antibiotics due to high cost, time-consuming

(c) The Author(s). 2019 Open Access This article is distributed under the terms of the Creative Commons Attribution 4.0 International License (http://creativecommons.org/licenses/by/4.0/), which permits unrestricted use, distribution, and reproduction in any medium, provided you give appropriate credit to the original author(s) and the source, provide a link to the Creative Commons license, and indicate if changes were made. The Creative Commons Public Domain Dedication waiver (http://creativecommons.org/publicdomain/zero/1.0/) applies to the data made available in this article, unless otherwise stated. 
and because bacterial agents rapidly develop resistance no sooner than they were discovered. Studies in recent years have suggested that most secondary metabolites (SM) in essential oil (EO) has better properties and might stand as a substitute against certain pathogenic bacterial strains [3-5].

Most often natural radical scavengers such as catalase, glutathione, peroxidase, superoxide dismutase, and others endogenous antioxidant are overwhelmed by radicals produced including hydroxyl ( $\mathrm{HO} \bullet$ ), lipid peroxyl $(\mathrm{LP} \bullet)$, nitric oxide $(\mathrm{NO} \bullet)$, superoxide (O2-) from metabolism and ecologically made stressor activities [4]. Consequently, oxidative stress diseases including arthritis, arteriosclerosis, Alzheimer, and cancers, among others grows with cellular injury [6]. Studies have shown that most SM in EO could function as a credible option to man-made antibiotics because they can effectively scavenge radicals and inhibit bacterial and fungus cell growth [7, 8]. Thymol, carvacrol, limonene, caryophyllene, and among others are examples of plant's SM that possess such bioactive properties $[8,9]$.

Azadirachta indica (Neem tree) is perhaps one of the most useful traditional medicinal plants especially in many tropical and subtropical countries. During the last three decades, apart from the chemistry of the neem essential oil compounds, considerable progress has been achieved on the organic and aqueous extracts biological activity as well as medicinal applications. The solvent extracts were reported to contain bioactive SM including nimbandiol, azadirachtin and nimbinin and natural steroids $[10,11]$. Several articles on the usefulness and composition of the seed oil have been published [11-13]. However, there is a dearth of information on the comparative study of the bioactivity of neem cosmetics as well as effects of $A$. indica secondary metabolites (AISM) from the seed oil, leaves and stem-bark EOs on neem products. Such study will unveil the chemistry and broadened the bioactivity knowledge of the plant extracts and amplify it utilizations against infections including ingrown nail, eczema, pimples and skin cancers. We aimed to investigate in vitro the inhibitory effects of soap and cream produced with the neem seeds oil and EOs against some selected infectious pathogens and oxidative stress radicals.

\section{Methods}

\section{Collection and processing of materials}

The chemicals and reagents used included the following: Mueller Hinton agar from Oxford Ltd. (Hampshire, England), Dimethyl sulfoxide (DMSO) from Fluka Chemicals (Buchs, Switzerland). 2, 2-diphenyl-1-picrylhydrazyl (DPPH) were bought from Sigma - Aldrich (St Louis, USA). Reagents used were all analytical grade. The industrial cosmetics chemicals (caustic sodium, sodium silica, glycerol, shea butter, sodium citrate, cetyl alcohol, stearic acid, vitamin E, and propylparaben were bought from industrial soap and cosmetics market Ojota, Lagos, Nigeria. The $A$. indica dried seed $(500 \mathrm{~g})$ was bought from National research institute for chemical technology, Zaria, Nigeria. The A. indica leaves (200 g) and stem-bark (200 g) were collected in July 2015 at the Digital Institute Bridge, Lagos, Nigeria. A plant taxonomist (Mr. T.K. Odewo) at the Department of Botany, University of Lagos authenticated the three samples (neem seed, leaf, and stem-bark). The three voucher specimens (reference numbers LUH 2009A, LUH2009B, and LUH2009C) were kept in the Lagos University herbarium (LUH). The neem seed oil (fixed oil) was extracted with Federal Institute of industrial research Lagos Nigeria mechanical cold press at room temperature $\left(25.3 \pm 2^{\circ} \mathrm{C}\right)$. The EOs were extracted from the air-dried leaves and stem-bark as described in the previous report [14]. The yield of each extract was calculated per gram of the plant material and the EOs were kept in vials at 4 o $\mathrm{C}$ until further analysis.

\section{Analysis of the extracted oils and neem cosmetics produced}

The physicochemical properties of the neem oil (NMO) and neem soap were performed using guidelines of AOAC [15] and as described by Fatiany et al. [16]. (a) Acid value: The AV (mg/ KOH/g) of the NMO was evaluated by neutralizing the free acids by $\mathrm{KOH}$; (b) Saponification value (SV): The SV (mg/ $\mathrm{KOH} / \mathrm{g})$ was calculated as the quantity of $\mathrm{KOH}$ necessary to saponify esters of acids and to neutralize the free acids in one gram of the NMO; (c) Ester index (EI): The EI was quantified as the difference between the SV and the AV. (d) Relative density (RD): The RD was measured with an Anton Paar $\mathrm{GmbH}$ dosimeter (DMA35N USA); (e) Refractive index (RI): The neem oil RI was measured at $38^{\circ} \mathrm{C}$ with a digital refractometer (ATC95200-009 France). The physicochemical parameters $(\mathrm{pH}$, moisture, total fatty matter, total free caustic alkali, unsaponifiable matter, matter insoluble in ethanol and water) of the neem soaps were carried out as described in Mak-Mensah et al. [17] report. The SM in the leaves EO (LEO) and stem-bark EO (SBEO) were analyzed by gas chromatography-mass spectrometry (GC/MS) and retention index (RI). The instrument used (Hewlett- Packed 5973 mass spectrometer linked with an HP 6890 gas chromatograph) was programmed as in our previous report [14]. Thereafter, the identification each SM was carried out by the conformity of their mass spectra data (MSD) with the reference held in the computer library (Wiley 275, New York). Furthermore, the retention index (RI) of the SM was matched with those in literature, while the total percentage composition of SM in each EO was their peak areas. 
Table 1 Neem soap recipe

\begin{tabular}{|c|c|c|c|c|c|c|c|c|c|}
\hline Neem oil & Shear butter & Caustic Soda & Sodium silicate & Deionized water & NMS Water ${ }^{a}$ & NMLEO & NMSBEO & NMLEO\& NMSBEOs ${ }^{\mathrm{b}}$ & Total \\
\hline $58.75(\% \mathrm{w} / \mathrm{w})$ & 4.00 & 10.00 & 4.65 & 21.00 & 0.40 & 0.40 & 0.40 & 0.40 & $100 \%$ \\
\hline
\end{tabular}

${ }^{\mathrm{a}} \mathrm{NMS}=$ negative control

${ }^{\mathrm{b}} \mathrm{NMLEO} \& \mathrm{NMSBEO}=$ neem leaves $\mathrm{EO}$ and neem stem-bark EO

\section{Production of neem cosmetics}

The neem soap (NMS) was produced using standard recipe Hui [18] for conventional toilet soap making with the neem seed oil substituted for palm kernel oil (PKO) which provides the triglyceride (fatty acid). The full boiled method was used to produce sample. Briefly, the weighed neem oil and shea butter (Table 1) were warmed at $60^{\circ} \mathrm{C}$. The oil was filtered and poured into a $500 \mathrm{~L}$ beaker. Caustic soda solution (10\% sodium hydroxide and $20 \%$ water) was added to the oil, stirred with a dried wooden stirrer for proper mixing. The mixture was heated, boiled and allowed to become slurry on continuous stirring. On cooling $\left(34^{\circ} \mathrm{C}\right)$, the slurry was divided into four equal weights, sodium silicate added to each and stirred properly. To the first part (NMS) no neem essential oil was added (as control), in the second part the extracted neem leaves EO was added (NMLEO), for the third part EO from stem-bark was added (NMSBEO), and the fourth contained both NMLEO and NMSBEO $(1,1)$. Each slurry was separately stirred for proper mixing and left in a separate wooden mound to solidify. Thereafter, they were cut into smaller sizes and left at ambient temperature for $48 \mathrm{~h}$ prior to analysis.

The neem cream was produced using varnishing base formulation by combining deionized water phase (DWP) and neem seed oil (NSO) as oil phase (OLP) with the use of the emulsifier as described by Hui [17]. Briefly, the OLP was prepared by combining all the waxes (Table 2) and NSO in a microwavable container and heat until they are melted at $82.2^{\circ} \mathrm{C}$. The DWP was made by heating water separately to $75^{\circ} \mathrm{C}$, thereafter citric acid, methylparaben, and propylparaben were dissolved. The mixture then added to the OLP and blended thoroughly. On cooling (32 o C) it was divided into four equal weights in sterilized beakers. Subsequently, the 4 different neem cream samples (NMC, NMCL, NMCSB, and NMCLSB + NMCSB) were produced in a similar model as described four soap samples. They were kept in sterilized bottles at ambient temperature prior to analysis.

\section{Antibacterial test}

Five reference bacterial strains and two laboratory strains from our laboratory stock culture confirmed to be multi-drug resistant bacteria $[19,20]$ were used for the antibacterial assay. The reference and laboratory strains bacteria are four Gram-positive: S. aureus (NCIB 50080), M. smegmatis (ATCC 700084), L. ivanovii, (ATCC 19119), S. uberis (ATCC700407) and three Gram-negative bacteria: E. cloacae (ATCC 13047), E. coli 180 and $V$. paraheamolyticues reported to be resistant to sulphamethoxazole, ampicillin, streptomycin, cefuroxime, cephalexin, tetracycline and nalidixic [21] were tested against the neem cosmetics (NC), following CLSI (2014) procedures. The bacterial suspensions were made by inoculating a fresh stock culture of the test bacteria strains into tubes containing $5 \mathrm{~mL}$ of sterile Luria Bertani broth and incubated for $24 \mathrm{~h}$ at $37^{\circ} \mathrm{C}$. Thereafter, active cultures were grown $24 \mathrm{~h}$ in sterile Luria- Bertani broth inoculated into Mueller-Hinton Agar (MHA) incubated for $24 \mathrm{~h}$ at $37^{\circ} \mathrm{C}$. After incubation, single colonies were transferred from MHA plates into $4 \mathrm{~mL}$ of normal saline solution determined spectrophotometrically at $580 \mathrm{~nm}$ as previously reported by Omoruyi et al. [22] and adapted by Igwaran et al. [23] and the dilutions matching with $0.5 \mathrm{Mc}$-Farland standards were used for the assay.

The modified method of Gullon et al. [24] was used for the determination of MIC and MBC of the neem cosmetics (NC). Under the aseptic condition, two-fold serial dilutions were carried in sterile microcentrifuge tubes in a total volume of $100 \mu \mathrm{L}$ of Muller Hinton $(\mathrm{MH})$ broth mixed with the $\mathrm{NC}$ of various concentrations ranging from $0.0125-0.800 \mathrm{mg} / \mathrm{mL}$. The positive and negative controls were ciprofloxacin and water respectively, thereafter they were incubated at $37^{\circ} \mathrm{C}$ for 24 $\mathrm{h}$. The was assay carried in triplicate and tubes with the lowest concentration without visible growth were reported as the minimum inhibitory concentration (MIC). The minimum bactericidal concentration $(\mathrm{MBC})$ for each neem product and the control were determined by streaking out all tubes without visible growth in the MIC technique into fresh nutrient agar plates. Then, at $37^{\circ} \mathrm{C}$, the culture was incubated for $24 \mathrm{~h}$. The lowest concentration of the cosmetics and ciprofloxacin that didn't on the solid medium yield any growth after $24 \mathrm{~h}$ [25] was recorded as the MBC.

Table 2 Neem cream recipe

\begin{tabular}{|c|c|c|c|c|c|c|c|c|c|c|}
\hline Neem oil & Emulsifier & Glycerol & Vitamin E & Sodium citrate & Propyl paraben & Cetyl alcohol & Stearic Acid & Deionized water & $\mathrm{NMC}^{\mathrm{a}}$ & Total \\
\hline $8.00(w / w)$ & 6.00 & 5.60 & 1.60 & 1.00 & 1.00 & 1.20 & 0.80 & 74.00 & 1.60 & $100 \%$ \\
\hline
\end{tabular}

${ }^{\mathrm{a}} \mathrm{NMC}=$ neem creams in four different models as in soap (NMC, NMLEO, NMSBEO NMLEO\& NMSBEO) 


\section{Antioxidant test}

Three antioxidant assays (DPPH, nitric oxide, and lipid peroxyl) were used to assess the radical scavenging property of neem cosmetics. The DPPH procedures of Liyana-Pathirana et al. [26] as described in the previous report [14] was followed to evaluate the neem cosmetics (NC) inhibitory potentials against DPPH radical in DMSO as diluent. The test was performed in triplicate and the capacity of NC to scavenge DPPH $\bullet$ to a neutral molecule (DPPH-H) was determined as \% scavenging effects with the eq. (1) below.

\%scavenging of DPPH•by $\mathrm{NC}$ or RCs

$$
=\{(\text { Abs cl }- \text { Abs sp })\} /(\text { Abs cl }) \times 100
$$

Where Abs cl is the absorbance of the DPPH radical + DMSO; Abs sp. is the absorbance of DPPH radical + NC or reference compounds (RCs).

The antioxidant potency of each $\mathrm{NC}$ and reference compound against the lipid peroxyl radical (LP •) were determined by the thiobarbituric acid assay as described in the previous report [14] with a known lipid-rich source (egg yolk). Subsequently, at $532 \mathrm{~nm}$ the absorbance of the solution was read after aspirating the upper organic layer. The scavenging efficacy of each $\mathrm{NC}$ and RCs against lipid peroxyl at increasing concentrations $(0.025-0.50 \mathrm{mg} / \mathrm{mL})$ was assessed with the eq. (1) above.

The sodium nitroprusside nitric oxide radical (NO•) induced protocol as described by Makhija et al. [27] was used to determine the NO. scavenging potential of the NC. At physiological pH 7.2, sodium nitroprusside nitric oxide decomposed generating $\mathrm{NO}$, which react in the presence of $\mathrm{O} 2$ and resultant stable nitrite and nitrate is measured in Griess solution. Briefly, $1.0 \mathrm{~mL}$ of the $\mathrm{NC}$ at double fold concentrations $(0.025-0.5 \mathrm{mg} / \mathrm{mL}$ prepared in DMSO) was added to $1.0 \mathrm{~mL}(10 \mathrm{mM})$ of sodium nitroprusside solution. The solution was incubated for $110 \mathrm{~min}$ at ambient temperature. Then followed the color development by adding $1.0 \mathrm{~mL}$ of the aliquot to Griess solution $(1.0 \% \quad \mathrm{~N}$-naphthyl-ethylene diamine hydrochloride in $2.0 \%$ orthophosphoric acid and $1.0 \%$, sulphanilamide). Thereafter, the absorbance of the color developed was then measured spectrophotometrically at $546 \mathrm{~nm}$ against the reagent blank. The scavenging effect (\%) was then obtained using equation (a) described in DPPH radical test. The assay was carried out in parallel triplicate and the mean value calculated. The IC50 (mg/ $\mathrm{mL}$ ) was obtained from the standard curve for each neem product and positive control in the three protocols. The lower the IC50 value the higher the antioxidant capacity.

\section{Cytotoxicity assay}

The in vitro hemolytic technique as illustrated by Helander et al. [28] was followed to assess the cytotoxicity of the NC with few modifications. Hemolytic test investigates hemoglobin discharge in the plasma (indicating red blood cell $[\mathrm{RBC}]$ lysis) due to contact with the test sample. Human RBC from one of our projects involving human blood was used in preparing blood agar plates (BAP). Wells were bored on the BAP at $0.10-0.70 \mathrm{mg} /$ $\mathrm{mL}$ prepared in deionized water. Then, into each well $25 \mu \mathrm{L}$ of the neem product was poured while BAP and well with only deionized water was used negative control. Thereafter, at $37{ }^{\circ} \mathrm{C}$, the plates incubated for $24 \mathrm{~h}$. The presence of hemolytic activity was examined on wells and the assay was carried in triplicate.

\section{Data analysis and calculations}

The significant difference between the neem product and controls were carried out by SPSS15.0 for windows (Institution registration No for IBM-SPSS/OLRAC SPS 2012/1786646/07). All protocols results were expressed as means $\pm \mathrm{S}$. D of duplicate in cytotoxicity assay while the antibacterial, antioxidant and physicochemical tests were performed in triplicate. Regression equation produced from the standard curve for each sample in the antioxidant assay was used to calculate the IC50 value for each NC and controls. T-Test correlation analysis was used to test significant differences between the \% radical scavenging and concentrations. The confidence level at $P<0.05$ was considered significant.

\section{Results}

\section{Inhibitory effects of cosmetics on pathogens}

The inhibitory effects (supporting document 1) of the neem cosmetics produced with and without AISM on test pathogens are as presented in Tables 3 and 4 . The antibacterial activities of the neem soaps produced with AISM (NMLS, NMSBS, and NMLSBS) were significantly different $(p<0.05)$ from those without AISM (NMS) with MIC values ranging between 0.0125 to $0.400 \mathrm{mg} /$ $\mathrm{mL}$ and 0.400 to $0.800 \mathrm{mg} / \mathrm{mL}$ respectively against the seven test pathogens. The NMS demonstrated a bacteriostatic effect on all test bacterial strains at $0.800 \mathrm{mg} /$ $\mathrm{mL}$, while the neem soap produced with AISM from the leaf EO (NMLS) was bactericidal against E. cloacae, $L$. ivanovii, S. aureus, and $V$. paraheamolyticues at 0.400 , $0.400,0.800$ and $0.800 \mathrm{mg} / \mathrm{mL}$ respectively. Unlike the NMS and NMLS, the neem soap made with AISM from the stem-bark EO (NMSBS) was bactericidal against all the test pathogens with MBC ranging between 0.100$0.800 \mathrm{mg} / \mathrm{mL}$. The neem soap prepared using AISMs from both leaf and stem-bark EOs (NMLSBS) exhibited the highest antibacterial effects with MIC and MBC values of 0.0125 and $0.025 \mathrm{mg} / \mathrm{mL}$ against $L$. ivanovii, and 0.025 and $0.200 \mathrm{mg} / \mathrm{mL}$ against $E$. cloacae. Interestingly the NMLSBS and positive control (ciprofloxacin) had same MIC value against L. ivanovii, while the MBC 
Table 3 Neem soap minimum inhibitory and minimum bactericidal concentrations (MIC and MBC)

\begin{tabular}{|c|c|c|c|c|c|c|c|c|c|c|c|}
\hline \multirow[t]{3}{*}{ Test Pathogens } & \multicolumn{8}{|c|}{ Neem Soap } & \multicolumn{3}{|l|}{ Controls } \\
\hline & \multicolumn{2}{|l|}{$\overline{N M S}$} & \multicolumn{2}{|l|}{ NMLS $^{a}$} & \multicolumn{2}{|l|}{ NMSBS $^{b}$} & \multicolumn{2}{|l|}{$\mathrm{NMLSBS}^{\mathrm{c}}$} & \multicolumn{2}{|c|}{ Ciprofloxacin $^{d}$} & \multirow{2}{*}{$\begin{array}{l}\text { Water } \\
\text { MIC } \\
500 \mu \mathrm{L}\end{array}$} \\
\hline & $\begin{array}{l}\mathrm{MIC} \\
\mathrm{mg} / \mathrm{mL}\end{array}$ & $\begin{array}{l}\mathrm{MBC} \\
\mathrm{mg} / \mathrm{mL}\end{array}$ & $\begin{array}{l}\mathrm{MIC} \\
\mathrm{mg} / \mathrm{mL}\end{array}$ & $\begin{array}{l}\mathrm{MBC} \\
\mathrm{mg} / \mathrm{mL}\end{array}$ & $\begin{array}{l}\mathrm{MIC} \\
\mathrm{mg} / \mathrm{mL}\end{array}$ & $\begin{array}{l}\mathrm{MBC} \\
\mathrm{mg} / \mathrm{mL}\end{array}$ & $\begin{array}{l}\mathrm{MIC} \\
\mathrm{mg} / \mathrm{mL}\end{array}$ & $\begin{array}{l}\mathrm{MBC} \\
\mathrm{mg} / \mathrm{mL}\end{array}$ & $\begin{array}{l}\mathrm{MIC} \\
\mathrm{mg} / \mathrm{mL}\end{array}$ & $\begin{array}{l}\mathrm{MBC} \\
\mathrm{mg} / \mathrm{mL}\end{array}$ & \\
\hline L. ivanovii & $\begin{array}{l}0.400 \pm \\
0.03\end{array}$ & $\begin{array}{l}0.800 \pm \\
0.01 \mathrm{VG}\end{array}$ & $\begin{array}{l}0.200 \pm \\
0.03\end{array}$ & $\begin{array}{l}0.400 \pm \\
0.01 \mathrm{NG}\end{array}$ & $\begin{array}{l}0.200 \pm \\
0.02\end{array}$ & $\begin{array}{l}0.400 \pm 0.01 \\
\text { NG }\end{array}$ & $\begin{array}{l}0.012 \pm \\
0.002\end{array}$ & $\begin{array}{l}0.025 \pm \\
0.001 \mathrm{NG}\end{array}$ & $\begin{array}{l}0.012 \pm \\
0.001\end{array}$ & $\begin{array}{l}0.05 \pm 0.01 \\
N G\end{array}$ & VG \\
\hline S. aureus & $\begin{array}{l}0.800 \pm \\
0.02\end{array}$ & $\begin{array}{l}0.800 \pm \\
0.10 \mathrm{VG}\end{array}$ & $\begin{array}{l}0.400 \pm \\
0.04\end{array}$ & $\begin{array}{l}0.800 \pm \\
0.01 \mathrm{NG}\end{array}$ & $\begin{array}{l}0.400 \pm \\
0.04\end{array}$ & $\begin{array}{l}0.400 \pm 0.03 \\
\text { NG }\end{array}$ & $\begin{array}{l}0.200 \pm \\
0.03\end{array}$ & $\begin{array}{l}0.200 \pm 0.02 \\
\text { NG }\end{array}$ & $\begin{array}{l}0.050 \pm \\
0.001\end{array}$ & $\begin{array}{l}0.050 \pm 0.04 \\
\text { NG }\end{array}$ & VG \\
\hline M.smegmatis & $\begin{array}{l}0.400 \pm \\
0.04\end{array}$ & $\begin{array}{l}0.800 \pm \\
0.04 \mathrm{VG}\end{array}$ & $\begin{array}{l}0.400 \pm \\
0.12\end{array}$ & $\begin{array}{l}0.400 \pm \\
0.03 \mathrm{VG}\end{array}$ & $\begin{array}{l}0.400 \pm \\
0.04\end{array}$ & $\begin{array}{l}0.400 \pm 0.11 \\
\text { NG }\end{array}$ & $\begin{array}{l}0.200 \pm \\
0.04\end{array}$ & $\begin{array}{l}0.400 \pm 0.02 \\
\text { NG }\end{array}$ & $\begin{array}{l}0.050 \pm \\
0.02\end{array}$ & $\begin{array}{l}0.100 \pm 0.02 \\
\text { NG }\end{array}$ & $V G$ \\
\hline E. coli $180^{*}$ & $\begin{array}{l}0.800 \pm \\
0.03\end{array}$ & $\begin{array}{l}0.800 \pm \\
0.03 \text { VG }\end{array}$ & $\begin{array}{l}0.800 \pm \\
0.11\end{array}$ & $\begin{array}{l}0.800 \pm \\
0.04 \text { VG }\end{array}$ & $\begin{array}{l}0.400 \pm \\
0.02\end{array}$ & $\begin{array}{l}0.800 \pm 0.03 \\
\text { NG }\end{array}$ & $\begin{array}{l}0.400 \pm \\
0.01\end{array}$ & $\begin{array}{l}0.800 \pm 0.01 \\
\text { NG }\end{array}$ & $\begin{array}{l}0.050 \pm \\
0.01\end{array}$ & $\begin{array}{l}0.050 \pm 0.02 \\
\text { NG }\end{array}$ & $V G$ \\
\hline V.paraheamolyticues * & $\begin{array}{l}0.400 \pm \\
0.01\end{array}$ & $\begin{array}{l}0.800 \pm \\
0.03 \mathrm{VG}\end{array}$ & $\begin{array}{l}0.400 \pm \\
0.03\end{array}$ & $\begin{array}{l}0.800 \pm \\
0.03 \mathrm{NG}\end{array}$ & $\begin{array}{l}0.400 \pm \\
0.02\end{array}$ & $\begin{array}{l}0.800 \pm 0.03 \\
\text { NG }\end{array}$ & $\begin{array}{l}0.200 \pm \\
0.02\end{array}$ & $\begin{array}{l}0.400 \pm 0.01 \\
\text { NG }\end{array}$ & $\begin{array}{l}0.050 \pm \\
0.01\end{array}$ & $\begin{array}{l}0.050 \pm \\
0.01 \mathrm{NG}\end{array}$ & $V G$ \\
\hline E. cloacae & $\begin{array}{l}0.400 \pm \\
0.01\end{array}$ & $\begin{array}{l}0.800 \pm \\
0.04 \mathrm{VG}\end{array}$ & $\begin{array}{l}0.200 \pm \\
0.01\end{array}$ & $\begin{array}{l}0.400 \pm \\
0.02 \mathrm{NG}\end{array}$ & $\begin{array}{l}0.025 \pm \\
0.020\end{array}$ & $\begin{array}{l}0.100 \pm \\
0.010 \mathrm{NG}\end{array}$ & $\begin{array}{l}0.025 \pm \\
0.020\end{array}$ & $\begin{array}{l}0.200 \pm \\
0.010 \mathrm{NG}\end{array}$ & $\begin{array}{l}0.012 \pm \\
0.010\end{array}$ & $\begin{array}{l}0.012 \pm \\
0.001 \mathrm{NG}\end{array}$ & $V G$ \\
\hline S. uberis & $\begin{array}{l}0.800 \pm \\
0.02\end{array}$ & $\begin{array}{l}0.800 \pm \\
0.03 V G\end{array}$ & $\begin{array}{l}0.40 \pm \\
0.01\end{array}$ & $\begin{array}{l}0.800 \pm \\
0.04 \mathrm{VG}\end{array}$ & $\begin{array}{l}0.40 \pm \\
0.03\end{array}$ & $\begin{array}{l}0.800 \pm 0.03 \\
\text { NG }\end{array}$ & $\begin{array}{l}0.40 \pm \\
0.00\end{array}$ & $\begin{array}{l}0.800 \pm 0.01 \\
\text { NG }\end{array}$ & $\begin{array}{l}0.050 \pm \\
0.01\end{array}$ & $\begin{array}{l}0.050 \pm 0.01 \\
\text { NG }\end{array}$ & ND \\
\hline
\end{tabular}

$N M S=$ neem soap without neem essential oil

${ }^{a} \mathrm{NMLS}=$ neem soap with leaf EO

${ }^{b}$ NMSBS $=$ neem soap with neem stem-bark EO

${ }^{c} \mathrm{NMLSBS}=$ neem soap with the leaf and stem-bark EO

${ }^{\mathrm{d}}$ ciprofloxacin = positive control

eWater $=$ negative control

* confirmed bacterial resistant strains, VG = Visible growth (bacteriostatic), NG = No visible growth (bactericidal) on solid agar plate, ND = Not determined

$(0.025 \mathrm{mg} / \mathrm{mL})$ was significantly better than control drug [ciprofloxacin $(0.05 \mathrm{mg} / \mathrm{mL})]$ as shown in Table 3.

The four neem creams were generally less active against the seven pathogens compared to the neem soaps. Like the neem soaps, the neem creams produced with the AISM stem-bark and from both leaf and stembark EO (NMLSBC) had better effects against the pathogens (Table 4). However, at $0.800 \mathrm{mg} / \mathrm{mL}$ on E. cloacae, the four creams exhibited a similar effect, while NMLSBC displayed a superior MIC value $(0.400 \mathrm{mg} / \mathrm{mL})$

Table 4 Neem cream minimum inhibitory and minimum bactericidal concentrations (MIC \& MBC)

\begin{tabular}{|c|c|c|c|c|c|c|c|c|c|c|c|}
\hline \multirow{3}{*}{$\begin{array}{l}\text { Test } \\
\text { Pathogens }\end{array}$} & \multicolumn{8}{|c|}{ Neem cream } & \multicolumn{3}{|l|}{ Controls } \\
\hline & \multicolumn{2}{|l|}{ NMC } & \multicolumn{2}{|l|}{$\mathrm{NMLC}^{\mathrm{a}}$} & \multicolumn{2}{|l|}{ NMSBC $^{b}$} & \multicolumn{2}{|c|}{ NMLSBC ${ }^{c}$} & \multicolumn{2}{|c|}{ Ciprofloxacin $^{d}$} & \multirow{2}{*}{$\begin{array}{l}\text { Water }^{\mathrm{e}} \\
\text { MIC } \\
(500 \mu \mathrm{L})\end{array}$} \\
\hline & $\begin{array}{l}\text { MIC } \\
\mathrm{mg} / \mathrm{mL}\end{array}$ & $\begin{array}{l}\mathrm{MBC} \\
\mathrm{mg} / \mathrm{mL}\end{array}$ & $\begin{array}{l}\mathrm{MIC} \\
\mathrm{mg} / \mathrm{mL}\end{array}$ & $\begin{array}{l}\mathrm{MBC} \\
\mathrm{mg} / \mathrm{mL}\end{array}$ & $\begin{array}{l}\text { MIC } \\
\mathrm{mg} / \mathrm{mL}\end{array}$ & $\begin{array}{l}\mathrm{MBC} \\
\mathrm{mg} / \mathrm{mL}\end{array}$ & $\begin{array}{l}\mathrm{MIC} \\
\mathrm{mg} / \mathrm{mL}\end{array}$ & $\begin{array}{l}\mathrm{MBC} \\
\mathrm{mg} / \mathrm{mL}\end{array}$ & $\begin{array}{l}\text { MIC } \\
\mathrm{mg} / \mathrm{mL}\end{array}$ & $\begin{array}{l}\mathrm{MBC} \\
\mathrm{mg} / \mathrm{mL}\end{array}$ & \\
\hline ivanovii & $\begin{array}{l}0.800 \pm \\
0.03\end{array}$ & $\begin{array}{l}0.800 \pm 0.01 \\
V G\end{array}$ & $\begin{array}{l}0.400 \pm \\
0.02\end{array}$ & $\begin{array}{l}0.800 \pm 0.01 \\
N G\end{array}$ & $\begin{array}{l}0.400 \pm \\
0.02\end{array}$ & $\begin{array}{l}0.800 \pm 0.01 \\
N G\end{array}$ & $\begin{array}{l}0.400 \pm \\
0.02\end{array}$ & $\begin{array}{l}0.400 \pm 0.02 \\
N G\end{array}$ & $\begin{array}{l}0.012 \pm \\
0.001\end{array}$ & $\begin{array}{l}0.050 \pm 0.01 \\
N G\end{array}$ & VG \\
\hline S. aureus & $\begin{array}{l}0.800 \pm \\
0.02\end{array}$ & $\begin{array}{l}0.800 \pm 0.03 \\
\text { VG }\end{array}$ & $\begin{array}{l}0.800 \pm \\
0.04\end{array}$ & $\begin{array}{l}0.800 \pm 0.02 \\
V G\end{array}$ & $\begin{array}{l}0.800 \pm \\
0.03\end{array}$ & $\begin{array}{l}0.800 \pm 0.03 \\
N G\end{array}$ & $\begin{array}{l}0.400 \pm \\
0.03\end{array}$ & $\begin{array}{l}0.800 \pm 0.02 \\
\text { NG }\end{array}$ & $\begin{array}{l}0.050 \pm \\
0.001\end{array}$ & $\begin{array}{l}0.050 \pm 0.04 \\
\text { NG }\end{array}$ & $V G$ \\
\hline $\begin{array}{l}\text { M. } \\
\text { smegmatis }\end{array}$ & $\begin{array}{l}0.800 \pm \\
0.01\end{array}$ & $\begin{array}{l}0.800 \pm 0.02 \\
V G\end{array}$ & $\begin{array}{l}0.400 \pm \\
0.02\end{array}$ & $\begin{array}{l}0.800 \pm 0.03 \\
\text { NG }\end{array}$ & $\begin{array}{l}0.800 \pm \\
0.02\end{array}$ & $\begin{array}{l}0.800 \pm 0.01 \\
\text { NG }\end{array}$ & $\begin{array}{l}0.400 \pm \\
0.04\end{array}$ & $\begin{array}{l}0.800 \pm 0.02 \\
\text { NG }\end{array}$ & $\begin{array}{l}0.05 \pm \\
0.02\end{array}$ & $\begin{array}{l}0.100 \pm 0.02 \\
\text { NG }\end{array}$ & $V G$ \\
\hline E. coli $180^{*}$ & $\begin{array}{l}0.800 \pm \\
0.03\end{array}$ & $\begin{array}{l}0.800 \pm 0.03 \\
\text { VG }\end{array}$ & $\begin{array}{l}0.800 \pm \\
0.01\end{array}$ & $\begin{array}{l}0.800 \pm 0.02 \\
\text { VG }\end{array}$ & $\begin{array}{l}0.800 \pm \\
0.01\end{array}$ & $\begin{array}{l}0.800 \pm 0.01 \\
V G\end{array}$ & $\begin{array}{l}0.800 \pm \\
0.02\end{array}$ & $\begin{array}{l}0.800 \pm 0.04 \\
V G\end{array}$ & $\begin{array}{l}0.050 \pm \\
0.01\end{array}$ & $\begin{array}{l}0.050 \pm 0.02 \\
\text { NG }\end{array}$ & $V G$ \\
\hline $\begin{array}{l}\text { V.paraheam- } \\
\text { olyticues * }\end{array}$ & $\begin{array}{l}0.800 \pm \\
0.02\end{array}$ & $\begin{array}{l}0.800 \pm 0.03 \\
\text { VG }\end{array}$ & $\begin{array}{l}0.800 \pm \\
0.01\end{array}$ & $\begin{array}{l}0.800 \pm 0.00 \\
V G\end{array}$ & $\begin{array}{l}0.800 \pm \\
0.11\end{array}$ & $\begin{array}{l}0.800 \pm 0.03 \\
V G\end{array}$ & $\begin{array}{l}0.800 \pm \\
0.04\end{array}$ & $\begin{array}{l}0.800 \pm 0.03 \\
V G\end{array}$ & $\begin{array}{l}0.050 \pm \\
0.01\end{array}$ & $\begin{array}{l}0.050 \pm 0.03 \\
\text { NG }\end{array}$ & VG \\
\hline E. cloacae & $\begin{array}{l}0.800 \pm 0 \\
02\end{array}$ & $\begin{array}{l}0.800 \pm 0.04 \\
\text { NG }\end{array}$ & $\begin{array}{l}0.800 \pm \\
0.12\end{array}$ & $\begin{array}{l}0.800 \pm 0.03 \\
N G\end{array}$ & $\begin{array}{l}0.400 \pm 0 . \\
02\end{array}$ & $\begin{array}{l}0.800 \pm 0.01 \\
N G\end{array}$ & $\begin{array}{l}0.400 \pm \\
0.02\end{array}$ & $\begin{array}{l}0.800 \pm 0.04 \\
\text { NG }\end{array}$ & $\begin{array}{l}0.012 \pm \\
0.001\end{array}$ & $\begin{array}{l}0.012 \pm 0.00 \\
N G\end{array}$ & ND \\
\hline S. uberis & $\begin{array}{l}0.800 \pm \\
0.02\end{array}$ & $\begin{array}{l}0.800 \pm 0.01 \\
V G\end{array}$ & $\begin{array}{l}0.800 \pm \\
0.01\end{array}$ & $\begin{array}{l}0.800 \pm 0.03 \\
V G\end{array}$ & $\begin{array}{l}0.800 \pm \\
0.03\end{array}$ & $\begin{array}{l}0.800 \pm 0.02 \\
N G\end{array}$ & $\begin{array}{l}0.400 \pm \\
0.01\end{array}$ & $\begin{array}{l}0.800 \pm 0.04 \\
N G\end{array}$ & $\begin{array}{l}0.050 \pm \\
0.01\end{array}$ & $\begin{array}{l}0.050 \pm 0.04 \\
\text { NG }\end{array}$ & ND \\
\hline
\end{tabular}

NMS neem cream without neem EO

${ }^{a} \mathrm{NMLC}=$ neem cream with leaf EO, NMSBC = neem cream with stem-bark neem EO

${ }^{\mathrm{C}} \mathrm{NMLSBC}=$ neem soap with leaf $\mathrm{EO}$ and stem-bark EO

$d$ amphotericin $B=$ positive control

eWater $=$ negative control, $P<0.05$

* confirmed bacterial resistant strains 
. The NMLSBC displayed higher inhibitory effects than other neem cream products with lower MBC values against the five test pathogens, however, its effect was lower than that of positive control drug (Table 4).

\section{Radicals scavenging effects of neem cosmetics}

The effects of AISM from leaf and stem-bark EOs on the radical scavenging property of neem soaps (NMLS, NSBS, and NMLSBS), creams (NMC, NMLC, NMSBC and NMLSBC) as well as neem cosmetics (NMS and NMC) produced devoid of AISM were examined on three different radicals (DPPH •, LP •, and NO •). The radical scavenging effects of neem soaps and positive control (ascorbic acid and rutin) on the radicals were concentration dependent (Figs. 1, 2 and 3). At low concentration, Table $5(0.10 \mathrm{mg} / \mathrm{mL})$ the neem soaps except for NMSBS scavenging effects on the three (DPPH, LP, and NO) radicals were significantly different \# $(p<0.05)$, while the effect of NMSBS against LP •, and NO • were similar (s). At a higher dose $(0.20 \mathrm{mg} / \mathrm{mL})$ all test neem soap samples scavenged the three radicals differently (Fig. 2). Similarly, at the highest concentration $(0.5 \mathrm{mg} /$ $\mathrm{mL}$ ) the neem soaps excluding the soap without AISM scavenging effects were significantly different \# $(<0.05)$ as showed in Fig. 3.

A substance that offers one or more hydrogen atoms to a radical converting the latter a non- radical molecule is referred to as a radical scavenger. This activity is shown as the color of DPPH • turns to yellow from purple (DPPH - solution) of the investigated substance because of formation of a neutral molecule of DPPH-H upon donation of $\mathrm{H}$ atom from the substance [29]. The strength of the examined radical scavenger is the reduction of UV absorbance at $517 \mathrm{~nm}$. However, DPPH
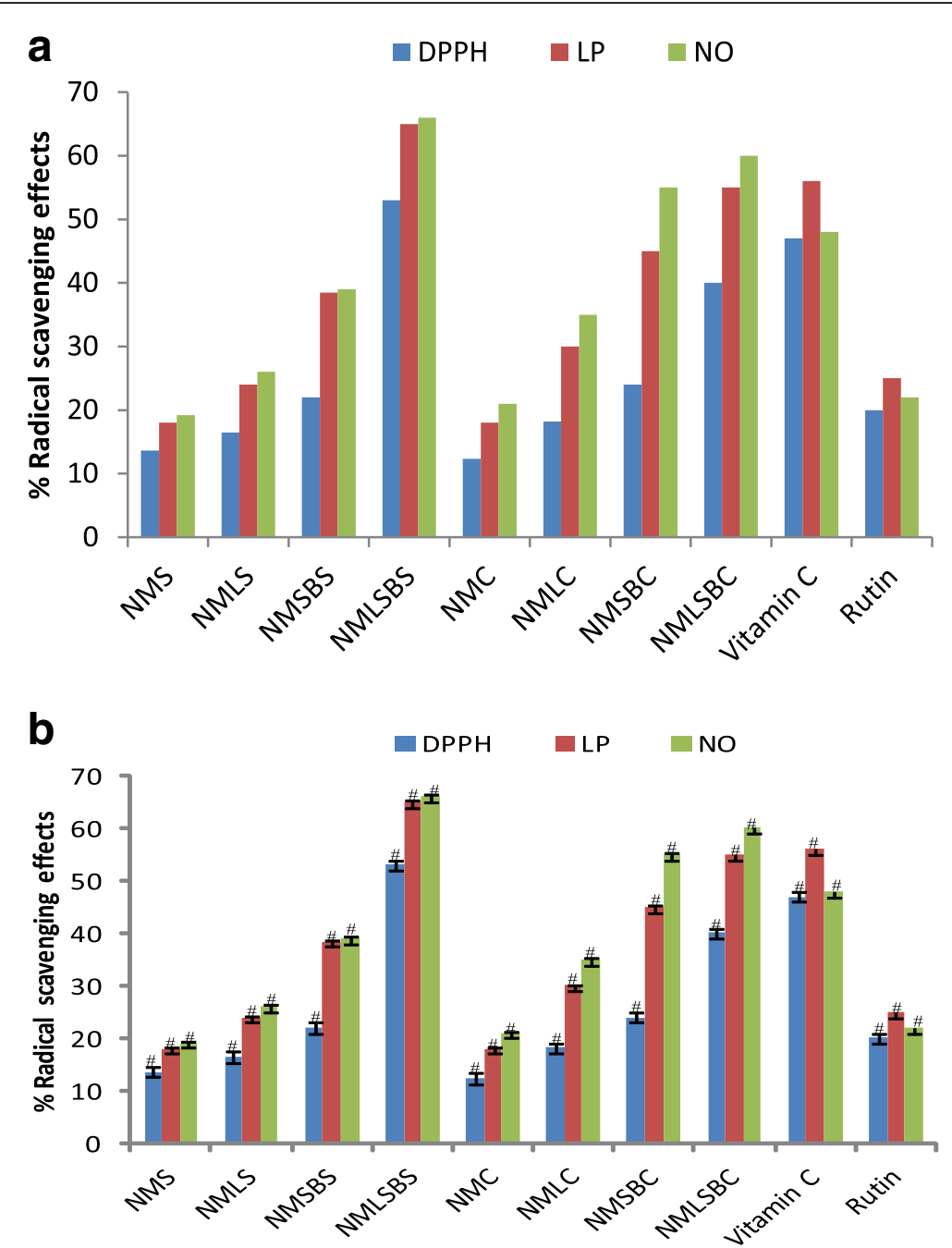

Fig. 1 a Radical scavenging effects of neem cosmetics with and without secondary metabolites and reference compounds at $0.10 \mathrm{mg} / \mathrm{mL}$. b Radical scavenging effects of neem cosmetics with and without secondary metabolites and reference compounds at $0.10 \mathrm{mg} / \mathrm{mL}$ (\#= significantly different, $\mathrm{s}=$ not significantly different $p<0.05)$ 


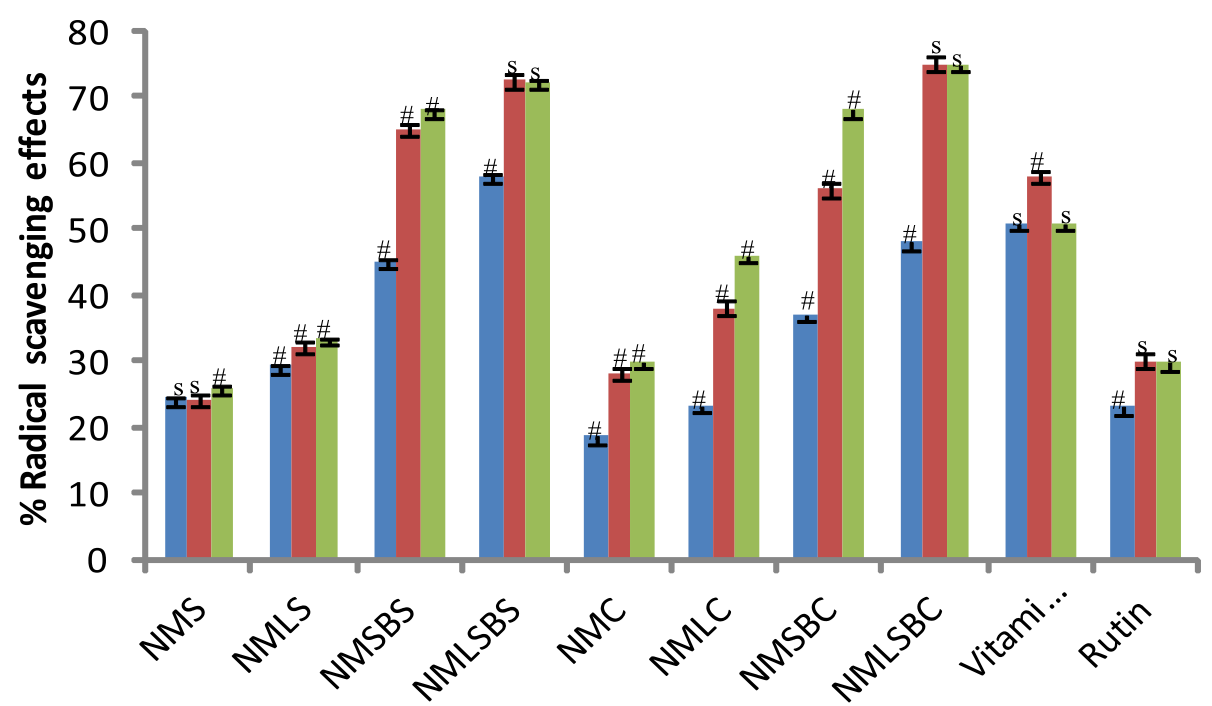

Fig. 2 Radical scavenging effects of neem cosmetics with and without secondary metabolites and reference compounds at $0.20 \mathrm{mg} / \mathrm{mL}$ (\# =significantly different, $\mathbf{s}=$ not significantly different $p<0.05$ )

technique doesn't distinguish radical type but an overall radical scavenging potency of a substance [14]. We therefore quantitatively tested presumed and précised inhibitory efficiency of each neem product by employing two different specific types of radicals (nitric oxide and lipid peroxyl) associated with skin inflammation, blood diseases, and other oxidative stress-related ailments. Evaluating the $\mathrm{IC}_{50}$ values for the different soaps and creams, regression equations from the standard curves generated for each radical was used while t-test analysis was employed for significantly different of \% radical scavenging effects against the concentrations (Figs. 1, 2 and 3). The neem cosmetics made without the AISM exhibited mild antioxidant capacity against nitric oxide, lipid peroxyl and DPPH radicals with IC50 values ranging between $4.78-6.50$ and $6.10-10.42 \mathrm{mg} / \mathrm{mL}$ for the soaps and creams respectively. The cosmetics produced using AISM from the neem leaf and stem-bark EOs

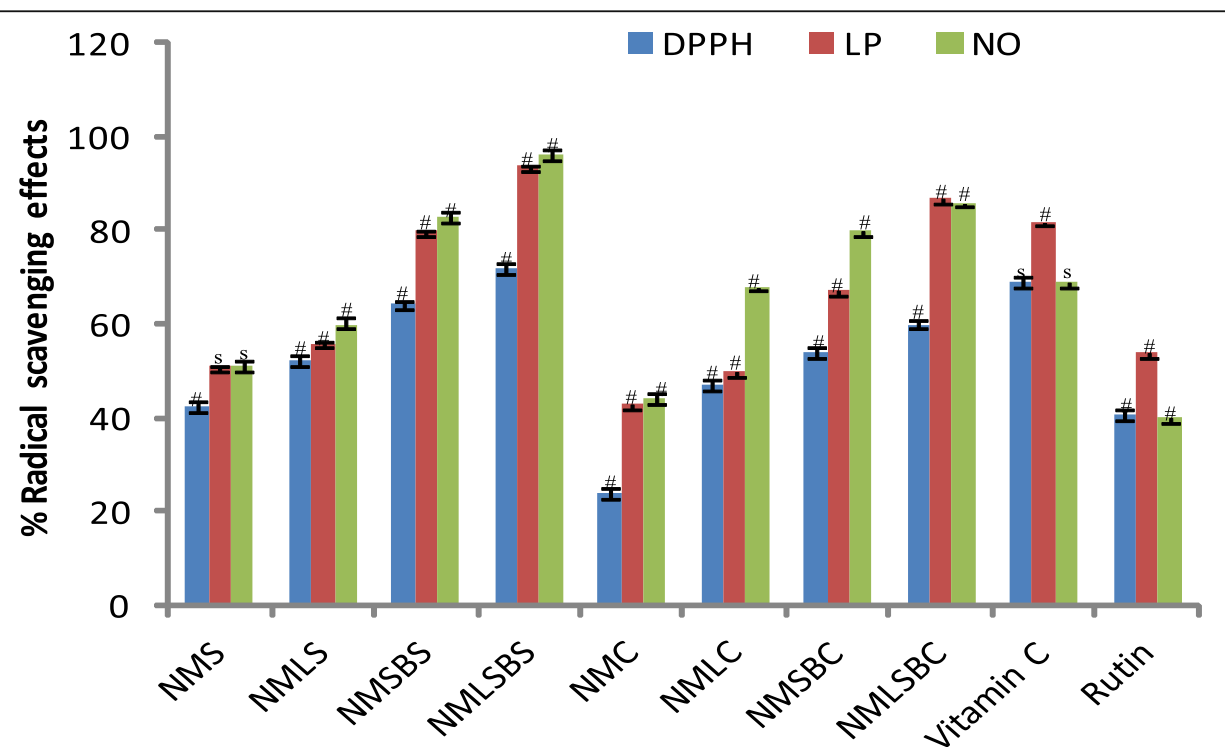

Fig. 3 Radical scavenging effects of neem cosmetics with and without secondary metabolites and reference compounds at $0.50 \mathrm{mg} / \mathrm{mL}$ (\# $=$ significantly different, $\mathbf{s}=$ not significantly different $p<0.05$ 
Table 5 Neem cosmetics scavenging effects on different radicals at $0.10 \mathrm{mg} / \mathrm{mL}$

\begin{tabular}{llll}
\hline NCs at $0.10 \mathrm{mg} / \mathrm{mL}$ & DPPH & LP & NO \\
\hline NMS & 13.6 & 18.0 & 19.2 \\
NMLS & 16.5 & 24.0 & 26.0 \\
NMSBS & 22.0 & 38.45 & 39.0 \\
NMLSBS & 53.0 & 65.0 & 36.0 \\
NMC & 12.3 & 18.0 & 21.0 \\
NMLC & 18.2 & 30.0 & 35.0 \\
NMSBC & 24.0 & 45.0 & 55.0 \\
NMLSBC & 40.0 & 55.0 & 60.0 \\
Vitamin C & 47.0 & 56.0 & 48.0 \\
Rutin & 20.0 & 25.0 & 22.0 \\
\hline
\end{tabular}

NMS \&NMC neem soap and cream without neem EOs, NMLS\& NMLC neem soap and cream containing leaf EO, NMSBS \& NMSBC neem soap and cream containing neem stem bark EO, NMLSBS \& NMLSBC neem soap and cream containing both leaf and stem bark EOs

demonstrated the highest antioxidant efficacy against three distinct radicals with $\mathrm{IC}_{50}$ values $1.65-2.60 \mathrm{mg} / \mathrm{mL}$ for the neem soap (NMLSBS). Interestingly, the antioxidant capacities of NMLSBS and NMLSBC were remarkably better than the two positive control drugs (Table 6) against LP and NO radicals associated with OSD.

\section{Physicochemical of properties of neem seed oil, essential oils, and neem cosmetics}

The physicochemical properties (PCP) of the crude neem seed oil (NSO) and essential oils (EOs) extracted by mechanical cold press and hydrodistillation from the aerial parts respectively are as presented in Table 7. Except a lower iodine value (IV) of $77.47 \%$ obtained, the

Table 6 Antioxidant capacity of neem cosmetics and reference compounds (mg/ mL)

\begin{tabular}{llll}
\hline $\begin{array}{l}\text { Neem samples } \\
\text { sand reference } \\
\text { compounds }\end{array}$ & DPPH & $\begin{array}{l}\text { Activity } \\
\text { LP }\end{array}$ & $\mathrm{NO} \cdot$ \\
\hline NMS $\left(I C_{50}\right)$ & $6.50 \pm 0.12$ & $5.81 \pm 0.03$ & $4.78 \pm 0.12$ \\
NMLS $\left(I C_{50}\right)$ & $5.50 \pm 0.01$ & $5.11 \pm 0.02$ & $4.06 \pm 0.02$ \\
NMSBS $\left(I C_{50}\right)$ & $4.30 \pm 0.10$ & $3.26 \pm 0.01$ & $3.06 \pm 0.03$ \\
NMLSBS $\left(I C_{50}\right)$ & $2.60 \pm 0.02$ & $1.75 \pm 0.03$ & $1.65 \pm 0.01$ \\
NMC $\left(I C_{50}\right)$ & $10.42 \pm 0.12$ & $6.23 \pm 0.03$ & $6.10 \pm 0.02$ \\
NMLC $\left(I C_{50}\right)$ & $5.48 \pm 0.01$ & $5.21 \pm 0.02$ & $3.94 \pm 0.02$ \\
NMSBC $\left(I C_{50}\right)$ & $5.10 \pm 0.10$ & $3.41 \pm 0.01$ & $2.49 \pm 0.03$ \\
NMLSBC $\left(I C_{50}\right)$ & $4.05 \pm 0.02$ & $2.23 \pm 0.03$ & $1.50 \pm 0.01$ \\
Rutin $\left(I C_{50}\right)^{*}$ & $5.74 \pm 0.02$ & $5.26 \pm 0.11$ & $4.80 \pm 0.04$ \\
Vitamin C $\left(I C_{50}\right)$ & $3.18 \pm 0.01$ & $2.28 \pm 0.03$ & $2.16 \pm 0.01$ \\
\hline
\end{tabular}

NMS \&NMC neem soap and cream without neem EOs, NMLS\& NMLC neem soap and cream containing leaf EO, NMSBS \& NMSBC neem soap and cream containing neem stem bark EO, NMLSBS \& NMLSBC neem soap and cream containing both leaf and stem bark EOs

"positive control drugs, $\pm S D, n=3$. $P<0.05$ was considered significant saponification, refractive index, and acid values of the NSO were similar to previous reports of neem seed oil $[17,30,31]$ and some vegetable oils used for cosmetics making, especially soap [32]. However, the IV in this present study was higher than the result obtained (63.81\%) for neem seed oil grown in Sudan [31, 33]. From Table 7, it can be noticed that the relative density (RD) of the NSO and the two EOs is less than 1. However, the RD of the crude NSO (0.921) was significantly lower $(p<0.05)$ than that reported for neem seed oil (0.939) by Akpan, [34] and higher (0.905) than that obtained in India [35]. The RD values for EO from leaves (0.0902) and stem-bark (0.904) was significantly different $\mathrm{p}<0.05$ from the crude NSO. The acid values of the EOs were found to be greater than NSO. Conversely, the ester, refractive indices and saponification values of the NSO were greater than that of leaf and stem-bark EOs.

The physicochemical properties of neem soaps produced with and without the AISM are as presented in Table 8 . The chemical properties of neem soaps were within the control limits of South Africa specifications for antibacterial toilet soap, Kenya standard for commercial toilet soap and standard Organisation of Nigeria (SON) for toilet soap [36-38], except the free caustic alkali $\left(0.32 \%\right.$ as $\left.\mathrm{Na}_{2} \mathrm{O}\right)$ for the neem soap (NMS) produced without AISM. Nevertheless, the total fatty matter (77.30-80.14\%) for the four neem soaps and other physicochemical parameters were better than the specifications of the SON for toilet soap and similar to neem soap produced elsewhere [17].

\section{Cytotoxicity of the neem cosmetics}

The cytotoxicity effects on neem cosmetics are as presented in Table 9. DMSO in blood agar without the cosmetics was used as negative control. The neem soap produced using AISM from both the leaf and stem bark (NMLSBS) exhibited low toxic (slight lysis) effect at $0.350 \mathrm{mg} / \mathrm{mL}$, while none of the cosmetics displayed acute toxic effect at less than $0.70 \mathrm{mg} / \mathrm{mL}$ on human RBC except NMLSBS.

\section{Secondary metabolites in the neem cosmetics}

The chemical profiles of secondary metabolites (SM) isolated from $A$. indica leaf and stem-bark incorporated unto the recipes of neem cosmetics are as presented in Table 10. In this current study terpenes and oxygenated terpenes (terpenoids) that were the chief SM, efficiently boosted the antibacterial and antioxidant properties of neem cosmetics. Fifteen SMs were found in the LEO, while the SBEO contained 19 which represents 98.91 and $99.45 \%$ of the total SM content respectively (Table $10)$. In the LEO, $\alpha$-caryophyllene, $\gamma$-elemene and hexadecane were the major sesquiterpenes, accounting for $44.30 \%$ of the overall SM content, while the total 
Table 7 Physicochemical of properties of neem oil and essential oil

\begin{tabular}{llll}
\hline Physicochemical Properties & Neem oil & Stem-bark EO \\
\hline Physical state & viscous liquid & Leaf EO $^{\mathrm{b}}$ & light viscous liquid \\
Colour & brownish & light viscous liquid & colourless \\
Odour & garlic repulsive & light yellow & repulsive \\
Relative density & $0.921 \pm 0.014$ & repulsive & $0.902 \pm 0.103$ \\
Acid value (1 $\mathrm{mg}$ of $\mathrm{KOH} / \mathrm{g}$ of oil) & $15.840 \pm 0.0021$ & $0.904 \pm 0.113$ & $19.630 \pm 0.001$ \\
Ester index & $172.201 \pm 0.012$ & $17.191 \pm 0.004$ & $53.150 \pm 1.866$ \\
Refractive index at $38^{\circ} \mathrm{C}$ & $1.4667 \pm 0.011$ & $74.930 \pm 4.311$ & $1.4372 \pm 0.201$ \\
Saponification value & $187.620 \pm 0.031$ & $1.4383 \pm 0.031$ & $72.780 \pm 0.011$ \\
lodine value $(\%)$ (g of $12 / 100 \mathrm{~g}$ of oil) & $77.470 \pm 0.011$ & $109.312 \pm 0.021$ & $\mathrm{ND}$
\end{tabular}

ail extracted from the neem seed by mechanical press

bessential oil extracted from the leaves and stem-bark by hydrodistillation, ND = not determined

monoterpenes, monoterpenoids and sesquiterpenoids SM were $22.70,10.50$ and $4.51 \%$ respectively. Conversely, in the SBEO there were fewer sesquiterpenes SM (24.21\%) compared to the SM in the LEO. However, there were more sesquiterpenoids $(23.70 \%)$ and monoterpenoids (19.80\%) SM in SBEO. The presence of bioactive SMs including a diterpenoid (phytol 9.21\%), curcumene (7.8\%), camphene (3.0\%), ledol (2.4\%) and tetracosane $(1.32 \%)$ in SBEO absent in LEO remarkably distinguished the chemical profile of the stem-bark EO from the leaf (Table 10). Furthermore, the yields of linalool oxide (15.2\%), terpinene (13.7\%), hexadecenoic acid (10.2\%) and polyunsaturated linoleic acid (5.40\%) were significantly higher in SBEO. This may corroborate the superior bioactive and physiochemical properties observed in neem stem-bark cosmetics products (NMSBEOS, NMLEOSNMSBEOS, NMSBEOC, NMLEOC-NMSBEOC) in this study.

\section{Discussion}

Biochemical investigations of inhibitory effects on pathogens and radicals of two different neem extracts (neem seed oil and EO) revealed higher bioactive and physicochemical properties of $\mathrm{NC}$ formulated with SM from the EO. Characterization of SM in the leaf and stem EOs integrated into the recipe of $\mathrm{NC}$ shown more terpenoids including phytol 18, one sesquiterpenoid (ledol 14), a monoterpene (camphene 2) and sesquiterpene (curcumene 8 ) in the stem-bark (SBEO). Moreover, the content of bioactive linoleic acid (17), hexadecenoic acid (15), caryophyllene oxide (12), linalool oxide (6) and terpinene (5) were more in SBEO. Accordingly, the NC made incorporating SMs from SBEO and LEO had the highest activity followed by NC produced with the SM from the SBEO, while NC produced with only crude neem seed oil (NSO) displayed the least activity. To the best of our knowledge, this enhanced bioactivity of neem cosmetics formulated from the leaves and stem bark of $A$. indica SMs are reported here for the first time in the genus Azadirachta. The neem cosmetics produced with AISM were more active against Gram-positive bacterial than the test Gramnegative bacterial strains. This may be linked to net repulsion of the complex outer membrane in Gramnegative bacterial, reported in previous studies to contain

Table 8 Physicochemical properties of neem soap and SON specifications for toilet soap

\begin{tabular}{|c|c|c|c|c|c|}
\hline Physicochemical Properties & NMS & NMLS & NMSBS & NMLSBS & $\begin{array}{l}\text { SON* } \\
\text { Control }\end{array}$ \\
\hline Colour & milky & milky & milky & milky & - \\
\hline pH. (10\%) & $9.60 \pm 0.03$ & $9.40 \pm 0.02$ & $9.36 \pm 0.03$ & $9.34 \pm 0.01$ & $9-11 \max ^{a}$ \\
\hline$\%$ Moisture content & $14.45 \pm 0.02$ & $12.50 \pm 0.00$ & $13.42 \pm 0.03$ & $13.36 \pm 0.02$ & 13-20 max \\
\hline \%Total fatty matter & $77.30 \pm 0.04$ & $77.68 \pm 0.00$ & $80.02 \pm 0.01$ & $80.14 \pm 0.02$ & 76.50 mini $^{b}$ \\
\hline Total free caustic alkali as $\mathrm{Na}_{2} \mathrm{O}$ & $0.32 \pm 0.03$ & $0.14 \pm 0.01$ & $0.12 \pm 0.02$ & $0.13 \pm 0.00$ & $0.20 \max$ \\
\hline$\%$ Matter insoluble in ethanol & $0.40 \pm 0.01$ & $0.03 \pm 0.04$ & $0.22 \pm 0.00$ & $0.20 \pm 0.02$ & $2.00 \max$ \\
\hline$\%$ Matter insoluble in water & $0.35 \pm 0.00$ & $0.33 \pm 0.02$ & $0.26 \pm 0.01$ & $0.23 \pm 0.04$ & $0.50 \max$ \\
\hline \% Unsaponified Matter & $0.23 \pm 0.01$ & $0.13 \pm 0.02$ & $0.04 \pm 0.01$ & $0.22 \pm 0.01$ & $0.50 \max$ \\
\hline Texture & Hard & very hard & very hard & very hard & - \\
\hline Leathering & Good & excellent & excellent & excellent & - \\
\hline
\end{tabular}

Standard organisation of Nigeria specifications for toilet soap $\pm \mathrm{SD}, n=3 . P<0.05$ was considered significant. NMS $=$ neem soap without neem EO, ${ }^{\text {a }}$ NMLS $=$ neem soap with leaf EO, NMLSBS = neem soap with leaf and stem bark EOs. $a=$ maximum limit, $b=$ minimum limit 
Table 9 Cytotoxic effect of neem cosmetics on human blood $\mathrm{RBC}$

\begin{tabular}{llllllll}
\hline Sample & \multicolumn{7}{l}{ Concentration $(\mathrm{mg} / \mathrm{mL})$} \\
\cline { 2 - 7 } & 0.10 & 0.15 & 0.20 & 0.25 & 0.30 & 0.35 & 0.70 \\
\hline NMS & - & - & - & - & - & - & - \\
NMLS & - & - & - & - & - & - & + \\
NMSBS & - & - & - & - & - & - & ++ \\
NMLSBS & - & - & - & - & - & + & +++ \\
NMC & - & - & - & - & - & - & - \\
NMLC & - & - & - & - & - & - & - \\
NMSBC & - & - & - & - & - & - & - \\
NMLSBC & - & - & - & - & - & - & + \\
Water $^{\mathrm{a}}$ & - & - & - & - & - & - & - \\
\hline
\end{tabular}

${ }^{a}$ water in blood agar without cosmetics; $-=$ No lysis (no toxic effect); $+=$ slight lysis (low toxic effect); $++=$ mild lysis (moderate toxic effect); $+++=$ acute lysis (sever toxic effect hydrophilic lipopolysaccharide which exhibits higher tolerance toward hydrophobic terpenes and oxygenated terpenes $[4,39]$. Another probable cause of resistance is the presence of multi-drug resistant sites that promote the synthesis and secretion of amphipathic toxins [40].

Phytol one of the major SM in the SBEO was reported [41] to demonstrate good antioxidant effects in vivo and has a high capacity to quench hydroxyl and nitric oxide radicals as well as prevent the formation of lipid peroxides analyzed via thiobarbituric acid reactive substances (TBARS). Phytol may have possibly reacted with nitric oxide, lipid, DPPH radicals, and the seven test bacterial strains via various mechanisms suggested by Mortein et al. and Foti and Amorati [4, 42]. In addition, terpinene a major SM we found in SBEO of A. indica is known to inhibit low-density lipoprotein oxidation even in the early phase [4]. Other bioactive SMs in EO profile including camphene [43], pinene [44] and linoleic acid [45] may have heightened the anti-oxidation and inhibition effects of the $\mathrm{NC}$ on radicals and the test pathogens.

Table $\mathbf{1 0}$ Chemical profiles of secondary metabolites in A. indica essential oils

\begin{tabular}{|c|c|c|c|c|c|c|c|c|}
\hline \multirow{2}{*}{$\begin{array}{l}\mathrm{S} / \\
\mathrm{N}\end{array}$} & \multirow[t]{2}{*}{$S M^{a}$} & \multirow[t]{2}{*}{$\mathrm{Kl}^{\mathrm{b}}$} & \multicolumn{2}{|c|}{ \%composition } & \multirow[t]{2}{*}{$\mathrm{Ml}^{\mathrm{C}}$} & \multirow{2}{*}{$\underset{\mathrm{d}}{\mathrm{QA}}$} & \multirow[t]{2}{*}{ MS data ${ }^{e}$} & \multirow[t]{2}{*}{$\mathrm{MF}^{*}$} \\
\hline & & & LEO & SBEO & & & & \\
\hline 1 & a-Pinene & 927 & 4.10 & 0.50 & MSD, Kl & 99 & $79,93,136$ & $\mathrm{C}_{10} \mathrm{H}_{16}$ \\
\hline 2 & Camphene & 944 & - & 3.00 & MSD, KI & 97 & $93,69,136$ & $\mathrm{C}_{10} \mathrm{H}_{16}$ \\
\hline 3 & Myrcene & 970 & 5.60 & $\mathrm{t}$ & MSD, KI & 99 & $41,93,69$ & $\mathrm{C}_{10} \mathrm{H}_{16}$ \\
\hline 4 & Limonene & 1031 & 10.4 & 5.50 & MSD, KI & 98 & $68,93,79$ & $\mathrm{C}_{10} \mathrm{H}_{16}$ \\
\hline 5 & Terpinene & 1063 & 2.70 & 13.70 & MSD, KI & 96 & $77,93,121$ & $\mathrm{C}_{10} \mathrm{H}_{16}$ \\
\hline 6 & Linalool oxide & 1068 & 6.40 & 15.20 & MSD, KI & 99 & $91,41,43$ & $\mathrm{C}_{10} \mathrm{H}_{16}$ \\
\hline 7 & Linalool & 1089 & 4.10 & 4.60 & MSD, KI & 95 & $44,71,113$ & $\mathrm{C}_{10} \mathrm{H}_{18} \mathrm{O}$ \\
\hline 8 & $\beta$-Curcumene & 1120 & - & 7.81 & MSD, KI & 97 & $109,161,43$ & $\mathrm{C}_{15} \mathrm{H}_{22}$ \\
\hline 9 & a-Cedrene & 1129 & 2.20 & $\mathrm{t}$ & MSD, KI & 91 & $93,41,204$ & $\mathrm{C}_{15} \mathrm{H}_{24}$ \\
\hline 10 & a-Cubebene & 1369 & 1.60 & 3.00 & MSD, KI & 97 & $43,68,161$ & $\mathrm{C}_{15} \mathrm{H}_{24}$ \\
\hline 11 & $\gamma$-Elemene & 1385 & 10.20 & 5.10 & $\mathrm{MSD}, \mathrm{KI}$ & 99 & $43,68,204$ & $\mathrm{C}_{15} \mathrm{H}_{24}$ \\
\hline 12 & a- Caryophyllene & 1415 & 30.30 & 8.30 & MSD, KI & 98 & $93,41,79$ & $\mathrm{C}_{15} \mathrm{H}_{24}$ \\
\hline 13 & Caryophyllene oxide & 1545 & 2.40 & 5.10 & MSD, KI & 98 & $41,79,111$ & $\mathrm{C}_{15} \mathrm{H}_{24} \mathrm{O}$ \\
\hline 14 & Ledol & 1560 & - & 2.40 & MSD, Kl & 96 & $93,79,133$ & $\mathrm{C}_{15} \mathrm{H}_{26} \mathrm{O}$ \\
\hline 15 & Hexadecanoic acid & 1968 & 5.40 & 10.20 & $\mathrm{MSD}, \mathrm{Kl}$ & 96 & $43,60,73$ & $\mathrm{C}_{16} \mathrm{H}_{32} \mathrm{O}_{2}$ \\
\hline 16 & Heptadecane & 2030 & 2.40 & 2.30 & MSD, KI & 95 & $43,60,256$ & $\mathrm{C}_{17} \mathrm{H}_{36}$ \\
\hline 17 & Linoleic acid & 2039 & 2.11 & 5.40 & MSD, KI & 98 & $73,265,279$ & $\mathrm{C}_{18} \mathrm{H}_{32} \mathrm{O}$ \\
\hline 18 & Phytol & 2045 & - & 9.12 & MSD, KI & 99 & $41,71,123$ & $\mathrm{C}_{20} \mathrm{H}_{40} \mathrm{O}$ \\
\hline 19 & Tetracosane & 2105 & - & 1.32 & MSD, KI & 98 & $73,43,129$ & $\mathrm{C}_{24} \mathrm{H}_{50}$ \\
\hline \multicolumn{2}{|c|}{$\%$ Total } & & 98.91 & 99.45 & & & & \\
\hline \multicolumn{2}{|c|}{$\%$ Yield } & & 0.72 & 0.58 & & & & \\
\hline
\end{tabular}

${ }^{\mathrm{a} S e c o n d a r y}$ metabolites listed in order of elution from HB-5 column

${ }^{b}$ Retention indices relative to $C_{9}-C_{25}$ n-alkanes on column

'methods of identification (mass spectra data $\& \mathrm{KI}=$ retention index)

dQuality assurance of GC/MS library

emass spectra data

"molecular formula $\mathrm{t} \leq 0.03 \%$, LEO = leaves essential oil, SBEO = stem bark essential 


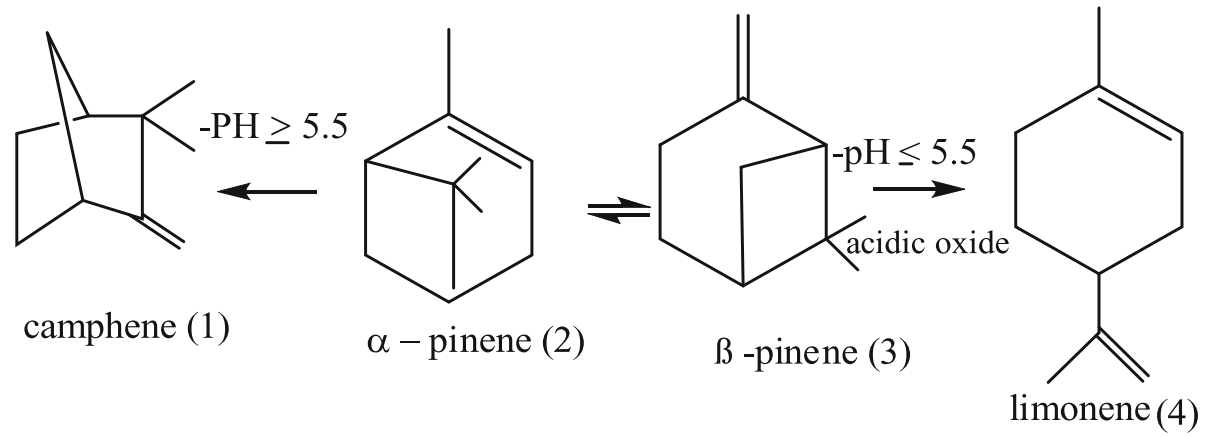

Fig. 4 Chemical transformation of some secondary metabolites

Based on their chemical structure, bioactive SMs are primarily terpenoids, terpenes, phenylpropenes and transformed products that originate either from terpenes, and unsaturated fatty acids [46] prominent in the EOs of $A$. indica, especially in the stem-bark (Table 10). This indicates the possibility of transformation of SM in the stem-bark and the entire parts of $A$. indica. A study by Gomes et al. [47] on the variation of SM in EO plants parts, revealed that limonene and caryophyllene are the most SMs that contribute frequently for the monoterpenes and sesquiterpenes biotransformation in EOs. This report supports the results we obtained as shown in the varied quantities of limonene and caryophyllene we found in the EOs; which might have transformed due to stress factors including temperature and $\mathrm{pH}$. Study on SMs by Corma et al. [48] shown that these terpenes are $\mathrm{pH}$ sensitive and are bio-transformed via isomerization (Fig. 4).

The comparison of inhibitory effects of NC and commercial antiradicals as well as standard antibiotics is a demonstrable strong indication of $\mathrm{NC}$ produced as an antibacterial and antioxidant agent especially the neem products formulated from stem bark SM. The ability of NMLSBS and NMLSBC to effectively reduced 3 types of free radicals to non-radical molecules and display significant bioactivity against five reference bacterial strains and two laboratory-confirmed multi-drug resistant bacterial strain is noteworthy. Therefore, the increased bioactive and physiochemical properties displayed by the SM in the neem cosmetics (NMSBS and NMSBC) indicates that the stembark EO will be feasible as a fresh potent source in the hunt for principal agent for the management of oxidative stressrelated ailments such as skin cancers [49], scabies, impetigo, and other related contagious skin diseases in this era of emerging multidrug resistance microorganisms.

None of the neem cosmetics displayed hemolytic effects on human red blood cells (HRBC) below $0.68 \mathrm{mg} /$ $\mathrm{mL}$. Mild cytotoxic effect was observed in neem soap formulated with combined stem-bark and leaf SMs at > $0.69 \mathrm{mg} / \mathrm{mL}$. This may be attributed to the frail nature of HRBC since there has never been any report on human toxicity after using a decoction of $A$. indica leaves and stem-bark in tropical and subtropical countries.

\section{Conclusion}

This present study indicates that besides the known uses neem tree, the neem cosmetics integrated with the stembark and leaf essential oil has robust bioactive secondary metabolites; therefore, the EO could be a novel applicant as new antimicrobial agent in this current era of rising multidrug-resistant bacterial strains, likewise as an alternative to synthetic antioxidant and effective bioactive chemical in pharmaceutical and cosmetics industries.

\section{Additional file}

Additional file 1: Screening of the products against 7 Bacterial strains at different concentrations. (DOCX $4399 \mathrm{~kb}$ )

\section{Abbreviations}

AISM: Azadirachta indica secondary metabolites; DMSO: Dimethyl sulphur oxide; DPPH•: 2,2-diphenyl-1-picrylhydrazyl radical; EOs: Essential oils; GCMS: Gas chromatography-mass spectrometry; IC50: Inhibitory concentration at 50\%; LP•: Lipid peroxide radical; MBC: Minimum bactericidal concentration; MIC: Minimum inhibition concentration; NC: Neem cosmetics; NMLS\& NMLC: Neem soap and cream containing leaf EO; NMLSBS \& NMLSBC: Neem soap and cream containing both leaf and stem bark EOs; NMO: Neem oil; NMS \&NMC: Neem soap and cream without neem EOs; NMSBS \& NMSBC: Neem soap and cream containing neem stem bark EO; NO•: Nitric oxide radical; OSD: Oxidative stress-related diseases

\section{Acknowledgments}

Authors are grateful to the University of Fort Hare, South Africa and Federal Institute of Industrial Research Oshodi, Lagos for providing a conducive environment for this study.

\section{Authors' contributions}

$\mathrm{SOO}$ and $\mathrm{OOO}$ designed the experiments, carried out the analysis, interpreted the results and wrote the article. AlO sought for funding, supervised the study and proofread the final manuscript. All authors have read and approved the final manuscript

Funding

The authors are thankful to South Africa Medical Research Council (SAMRC) and Govan Mbeki Research \& Development Centre (GMRDC) South Africa for financing this project. 


\section{Availability of data and materials}

All data and materials used in the study are in the manuscript also in the supplementary information files attached Additional file 1.

\section{Ethics approval and consent to participate}

Not applicable in this study.

\section{Consent for publication}

All authors agreed on the publication of this manuscript.

\section{Competing interests}

The authors declare that they have no competing interest.

\section{Author details}

'SAMRC Microbial Water Quality Monitoring Center, University of Fort Hare, Alice, South Africa. ${ }^{2}$ Applied and Environmental Microbiology Research Group (AEMREG), Department of Biochemistry and Microbiology, University of Fort Hare, Private Mail Bag X1314, Alice, Eastern Cape, South Africa. ${ }^{3}$ Department of Chemical, Environmental and Fibre Technology, FIIRO, Lagos, Nigeria. ${ }^{4}$ Department of Pure and Applied Chemistry, University of Fort Hare, Alice 5700 , South Africa.

Received: 9 March 2018 Accepted: 31 May 2019

Published online: 10 June 2019

\section{References}

1. Matias EF, Alves MK, Silva CR, Carvalho FA, Medeiros VC, Santos CE, Bitu FG, Souza AA, Figueredo ML, Boligon JG, Athayde HD. Costa et al. potentiation of antibiotic activity of amino glycosides by natural products from Cordia verbenacea DC. Micro. Pathog. 2016;95:111-6.

2. Poonam SL, Juhi T, Bibhabati M. Methicillin and vancomycin resistant $S$. aureus in hospitalized patients. J Global Infect Dis. 2010;2:275-83. https://doi. org/10.4103/0974-777X.68535.

3. Jindal BA, Pandya MK, Khan MI. Antimicrobial resistance: a public health challenge. Med J Armed Forc India. 2015;17:78-181.

4. Mortein H, Mygind TL, Rikke TM. Essential oils in food preservation: mode of action synergies and interactions with food matrix components. J Front Micro. 2012;3:12 PMC3265747.

5. Valente J, Zuzarte MJ, Gonçalves C, Lopes MC, Cavaleiro C, Cruz T. Antifungal, antioxidant and anti-inflammatory activities of $\mathrm{O}$. crocata $\mathrm{L}$. essential oil. Food Chem Toxicol. 2013;62:349-54

6. Murray AP, Rodriguez MA, Frontera MA, Mulet MC. Antioxidant metabolites from limonium brasiliene. Naturfo. 2004:59:477-80.

7. Helander IM, Akakomi H, Latva-Kala K, Mattila-Sandholm T, Pol I, Eddy J. Characterization of the action of selected essential oil components on gram-negative bacteria. J Agric Food Chem. 1998;46(9):3590-5. https://doi. org/10.1021/ff980154m.

8. Saikat S, Chakraborty R, Sridhar CY, Reddy SR, Biplab D. Free radicals, antioxidants, diseases and phytomedicine: current status and future prospect. Int J Pharm Sci Rev Res. 2010;3:91-100.

9. Tuttolomondo T, La Bella S, Licata M, Virga G, Leto C, Saija A, et al. Bimolecular characterization of wild Sicilian oregano: phytochemical screening of essential oils and extracts, and evaluation of their antioxidant activities. Chem Biodivers. 2013;10(3):411-33. https://doi.org/10.1002/cbdv. 201200219.

10. Mohammad MS, Forough M. Investigation of compounds from Azadirachta indica (neem). Asian J Plant Sci. 2007;6(2):444-5.

11. Nahak G, Sahu RK. Evaluation of antioxidant activity of flower and seed oil of Azadirachta indica. J Appl Nat Sci. 2011;3(1):78-81.

12. Jessinta S, Azhari HN, Saiful NT, Abdurahman HN. HN. Impact of geographic variation on physicochemical properties of neem (Azadirachta indica) seed oil. Int J Pharm Sci Res. 2014;5(10):4406-13. https://doi.org/10.13040/IJPSR. 0975-8232.5(10).440613.

13. Kumar PS, Mishra D, Ghosh G, Panda CS. Biological action and medicinal properties of various constituent of Azadirachta indica (Meliaceae) an overview. Annals of Biol Res. 2010;1:24-34.

14. Okoh SO, Iweriebor BC, Okoh OO, Nwodo UU, Okoh Al. Bactericidal and antioxidant properties of essential oils of the fruits Dennettia tripetala $\mathrm{G}$. baker. BMC Compl Altern Med. 2016;16:486. https://doi.org/10.1186/s12906016-1459-4.
15. AOAC. Official Methods of analysis, 20th Edition. Washington DC: Association of Official Analytical Chemists; 2016.

16. Fatiany RP, Robijaona B, Soavina S, Randrianirina O, Abdallah M, Fienena RF, Solofoniaina M, Marcelin JH, Raharisolalao N. GC-FID and GC/MS analyses and antimicrobial activity of Croton greveanus, C. borarium and C. geayi essential oils from Madagascar. J Pharm Phytochem. 2016;5:188-97.

17. Mak-Mensah EE, Firempong CK. Chemical characteristics of toilet soap prepared from neem (Azadirachta indica) seed oil. Asian J Plant Sci Res. 2011;1(4):1-7.

18. Hui FH, editor. Barley's industrial oil and fats products. 5th ed. New York: Wiley Interscience; 1996

19. Iweriebor BC, Iwu CJ, Obi LC, Nwodo UU, Okoh Al. Multiple antibiotic resistances among Shiga toxin producing Escherichia coli O157 in faces of dairy cattle farms in eastern cape of South Africa. BMC Microbiol. 2015;15: 213. https://doi.org/10.1186/s12866-015-0553-

20. Iwu CJ, Iweriebor BC, Obi LC, Basson AK, Okoh Al. Multidrug resistant Salmonella isolates from swine in the eastern cape province, South Africa. J Food Protect. 2016;79(7):1234-9. https://doi.org/10.4315/0362-028X.JFP-15-224.

21. Adefisoye MA, Okoh Al. Identification and antimicrobial resistance prevalence of pathogenic Escherichia coli strains from treated wastewater effluents in eastern cape, South Africa. Microbiologyopen. 2016;5(1):143-51.

22. Omoruyi BO, Afolayan AJ, Bradley G. The inhibitory effect of Mesembryanthemum edule (L.) bolus essential oil on some pathogenic fungal isolates. BMC Compl Altern Med. 2014;14(168):1-7.

23. Igwaran A, Iweriebor BC, Okoh SO, Nwodo UU, Obi LC, Okoh Al. Chemical constituents, antibacterial and antioxidant properties of the essential oil flower of Tagetes minuta grown in Cala community eastern cape, South Africa. BMC Compl Altern Med. 2017;17:351. https://doi.org/10.1186/s12906017-1861-6.

24. Gullon B, Pintado ME, Perez-Alvarez JA, Viuda-Martos M. Assessment of polyphenolic profile and antibacterial activity of pomegranate peel (Punica granatum) flour obtained from co-product of juice extraction. Food Cont. 2016;59:94-8.

25. Ramalivhana JN, Iweriebor BC, Obi CL, Samie A, Uaboi-Egbenni P, Idiaghe $\mathrm{JE}$, et al. Antimicrobial activity of honey and medicinal plant extracts against gram negative microorganisms. Afr J Biotechnol. 2014;13:616-25.

26. Liyana-Pathirana CM, Shahidi F. Antioxidant properties of the essential oils from lemon, grape, coriander, clove and their mixtures. J Sci Food Agric. 2006;86:477-85.

27. Makhija IK, Aswatha RN, Shreedhara CS, Vijay KS, Devkar R. In-vitro antioxidant studies of Sitopaladi Churna, a polyherbal Ayurvedic formulation. Free Rad Antioxid. 2011;1:37-41.

28. Helander IM, Akakomi H, Latva-Kala K, Mattila-Sandholm T, Pol I, Eddy J. Characterization of the action of selected essential oil components on gram-negative bacteria. J Agric Food Chem. 1998;46:3590-5. https://doi.org/ 10.1021/f980154m.

29. Guerrini A, Sacchetti G, Rossi D, Paganetto G, Muzzoli M, Andreotti E, et al. Bioactivities of Piper aduncum L. and Piper obliquum ruiz \& Pavon (Piperaceae) essential oils from eastern Ecuador. Environ Toxicol Pharmacol. 2009:27:39-48.

30. Erakhrumen AA. Evaluating the efficacy of neem (Azadirachta indica a. Juss) seed oil treatment for Bambusa vulgaris Schrad. Against Pycnoporus sanguineus Murr. Using static bending strength properties. For Pathol. 2011; 42(3):191-8. https://doi.org/10.1111/j.1439-0329.2011.00741.

31. Jessinta S, Azhari HN, Saiful NT, Abdurahman HN. Impact of geographic variation on physicochemical properties of neem (Azadirachta indica) seed oil. Int J Pharm Sc Res. 2014;5(10):4406-13.

32. Usman JG, Okonkwo PC. Modeling of extraction of oil from neem seed using Minitab 14 software. Chem Pro Engr Res. 14 online 2013, SSSN 2224-7467.

33. Falade SA, Adekunle MA, Aderogba OS, Atanda C, Harwood SR, Adewusi A. Physicochemical properties, total phenol and tocopherol of some Acacia seed oils. J Sci Food Agric. 2008;88:263-8.

34. Akpan (2000). Extraction and characterization of neem seed oil, In: Isong N, Alozie YE, Ekwere Y. Physicochemical properties of African walnut oil and its suitability for domestic and industrial uses. Nigerian J Agric Food Env. 2013; 9(3):12-5.

35. Muthu H, Sathyaselvabala V, Varathachary T, Kirupha T, Nandagopal D, Subramanian J. Synthesis of biodiesel from neem oil using sulfated zirconia via transesterification. Braz J Chem Eng. 2011;27(4):601-8. https://doi.org/10. 1590/S0104-66322010000400012.

36. Edict of Government, South Africa. Antibacterial solid toilet soap specification. South Africa: EAS 766 (English) ICS71.100.40; 2011. 
37. Onyango PV, Oyaro N, Aloys O, Mesopirr L, Omwoyo NW. Assessment of the physicochemical properties of selected commercial soaps manufactured and sold in Kenya. J Appl Sci. 2014;4:433-40.

38. SON. Specifications for toilet soap. Nigeria: Standard Organization of Nigeria. NIS 004: 2-8; 2006

39. Perussi JR. Photodynamic inactivation of microorganisms. Quim Nova. 2007; 30(4):988-94. https://doi.org/10.1590/\$0100-40422007000400039.

40. Garedew A, Schmolz E, Lamprechts I. Microbiological and calorimetric investigation on the antimicrobiobial actions of different propolis extracts: an in- vitro approach. Thermo Acta. 2014;422(1-2):115-24.

41. Santos CC, Salvadori MS, Mota VG, Costa LM, de Almeida AA, de Oliveira GA, et al. Antinociceptive and antioxidant activities of phytol in vivo and in vitro models. Neurosci J. 2013;2013:949452.

42. Foti MC, Amorati R. Non-phenolic radical-trapping antioxidants. J Pharm Pharmacol. 2009:6:1435-48. https://doi.org/10.1211/jpp.61.11.0002.

43. Vallianou I, Peroulis N, Pantazis P, Hadzopoulou-Cladaras M. Camphene, a plant-derived monoterpene, reduces plasma cholesterol and triglycerides in hyperlipidemic rats independently of HMG-CoA reductase activity. PLOS One. 2011;6:e20516.

44. Elanur A, Hasan T, Fatime G. Antioxidative, anticancer and genotoxic properties of a-pinene on N2a neuroblastoma cells. Biologia. 2013;68:10044009.

45. Yousefi S, Bayat S, Rahman MA, Ismail IS, Saki E, Leong SW, Abdulmalek E. Synthesis, bioactivity evaluation, and docking study of 5-aminosalicylic acid's fatty acid derivatives. Monatsh Chem. 2016;164(12):2139-49. https://doi.org/ 10.13140/RG.2.1.4110.7680

46. Khalid AK, El-Gohary AE. Effect of seasonal variations on essential oil production and composition of Plectranthus amboinicus (Lour.) grow in Egypt. Int Food Res J. 2014;21(5):1859-62.

47. Gomes PC, Oliveira HR, Vicente AM, Ferreira MF. Production, transformation and essential oils composition of leaves and stems of lemon verbena [Aloysia triphylla (L'Herit.) Britton] grown in Portugal. Rev. bra. Plant med. Botucatu. 2006:8:130-5.

48. Corma A, Iborra S, Velty A. Chemical routes for the transformation of biomass into chemicals. Chem Rev. 2007;102:2411-502. https://doi.org/10. 1021/cr050989d.

49. Paz-Elizur T, Sevilya Z, Leitner-Dagan Y, Elinger D, Roisman LC, Livneh Z. DNA repair of oxidative DNA damage in human carcinogenesis: potential application for cancer risk assessment and prevention. Cancer Lett. 2008: 266:60-72. https://doi.org/10.1016/j.canlet.2008.02.032.

\section{Publisher's Note}

Springer Nature remains neutral with regard to jurisdictional claims in published maps and institutional affiliations.

Ready to submit your research? Choose BMC and benefit from:

- fast, convenient online submission

- thorough peer review by experienced researchers in your field

- rapid publication on acceptance

- support for research data, including large and complex data types

- gold Open Access which fosters wider collaboration and increased citations

- maximum visibility for your research: over $100 \mathrm{M}$ website views per year

At BMC, research is always in progress.

Learn more biomedcentral.com/submissions 